\title{
Innate Lymphoid Cells (ILCs): Cytokine Hubs Regulating Immunity and Tissue Homeostasis
}

\author{
Maho Nagasawa, Hergen Spits, and Xavier Romero Ros \\ Department of Experimental Immunology, Academic Medical Center at the University of Amsterdam, 1105 BA \\ Amsterdam, Netherlands \\ Correspondence: hergen.spits@amc.uva.nl
}

\begin{abstract}
Innate lymphoid cells (ILCs) have emerged as an expanding family of effector cells particularly enriched in the mucosal barriers. ILCs are promptly activated by stress signals and multiple epithelial- and myeloid-cell-derived cytokines. In response, ILCs rapidly secrete effector cytokines, which allow them to survey and maintain the mucosal integrity. Uncontrolled action of ILCs might contribute to tissue damage, chronic inflammation, metabolic diseases, autoimmunity, and cancer. Here we discuss the recent advances in our understanding of the cytokine network that modulate ILC immune responses: stimulating cytokines, signature cytokines secreted by ILC subsets, autocrine cytokines, and cytokines that induce cell plasticity.
\end{abstract}

Innate lymphoid cells (ILCs) are innate lymphocytes that play important roles in immune defense against microbes, regulation of adaptive immunity, tissue remodeling, and repair and homeostasis of hematopoietic and nonhematopoietic cell types. ILCs are present in all tissues, but they are particularly enriched in mucosal surfaces. Unlike adaptive lymphocytes, ILCs do not possess rearranged antigen-specific cell receptors (T-cell receptor [TCR] or B-cell receptor $[\mathrm{BCR}])$, but they mirror $\mathrm{T}$ helper (Th) cell diversity regarding the secretion of signature cytokines and key transcription factors that regulate their differentiation and functions (Spits et al. 2013). ILCs develop from the common lymphoid progenitor (CLP) early in life and seed various tissues to become tissueresident lymphocytes (Diefenbach et al. 2014;
Klose et al. 2014; Gasteiger et al. 2015). ILCs cross talk with the resident tissue by sensing the cytokines present in their microenvironments and subsequently secreting a plethora of cytokines that regulate innate immunity and homeostasis of hematopoietic and nonhematopoietic cells in the tissues (Artis and Spits 2015). ILC dysregulation contributes to several pathological conditions, such as inflammatory bowel disease (IBD), chronic obstructive pulmonary disease (COPD), asthma, psoriasis, and atopic dermatitis (Artis and Spits 2015; Eberl et al. 2015). In this review, we will focus on the noncytotoxic ILC subsets, which are also termed as helper ILCs. We discuss the cytokines that influence ILC biology and the role of effector cytokines produced by ILCs in health and disease.

Editors: Warren J. Leonard and Robert D. Schreiber

Additional Perspectives on Cytokines available at www.cshperspectives.org

Copyright (C) 2018 Cold Spring Harbor Laboratory Press; all rights reserved; doi: 10.1101/cshperspect.a030304

Cite this article as Cold Spring Harb Perspect Biol 2018;10:a030304 
M. Nagasawa et al.

\section{ILC FAMILY AND SUBSETS}

All ILCs express the common cytokine receptor $\gamma$ chain $(\gamma c)$ together with interleukin (IL)-7 receptor (R) $\alpha$ (IL-7R $\alpha$, also called CD127), whereas killer ILCs, natural killer (NK) cells, and intraepithelial (ie) ILC1s, lack the expression of IL-7R but instead express IL-2R $\beta$ (also known as CD122) (Artis and Spits 2015; Eberl et al. 2015). ILCs are divided into three groups based on the expression of specific transcription factors and cell-surface molecules as well as their ability to secrete key cytokines (Table 1). Group 1 ILCs comprising NK cells and ILC1s produce interferon (IFN) $-\gamma$ in response to IL-12 and are dependent on T-bet; group 2 ILCs (ILC2s) preferential- ly produce type 2 cytokines (IL-5, IL-4, IL-9, and IL-13) in response to IL-33, IL-25, and thymic stromal lymphopoietin (TSLP) and rely on GATA3 as their key transactional factor; group 3 ILCs include ILC3s and lymphoid tissue inducer (LTi) cells endowed with the ability to secrete IL-17 and IL-22 in response to IL-1 $\beta$ and IL-23, and are functionally dependent on the transcription factor RAR-related orphan receptor $\gamma \mathrm{t}$ $(\mathrm{ROR} \gamma \mathrm{t})$.

\section{CYTOKINES REQUIRED FOR ILC DEVELOPMENT AND MAINTENANCE}

ILC ontogeny has been intensively studied particularly in mouse (Fig. 1). ILCs differentiate

Table 1. Mouse and human innate lymphoid cell (ILC) phenotypes

\begin{tabular}{|c|c|c|c|c|c|c|}
\hline \multirow[b]{2}{*}{ Group } & \multirow[b]{2}{*}{ Progenitor } & \multicolumn{2}{|l|}{ Mouse } & \multicolumn{2}{|l|}{ Human } & \multirow[b]{2}{*}{ Cytokines } \\
\hline & & Cell-surface molecules & TFs & Cell-surface molecules & TFs & \\
\hline \multirow[t]{3}{*}{1} & cNK & $\begin{array}{l}\text { CD122, CD49b, NK1.1, } \\
\text { NKG2A, NKp46, } \\
\text { IL-12RB1, CD25, } \\
\text { KLRG1 }\end{array}$ & $\begin{array}{l}\text { EOMES } \\
\text { T-bet }\end{array}$ & $\begin{array}{l}\text { CD122, NKG2A, NKp46, } \\
\text { NKp44 } 4^{+/-}, \text {IL-12RB1, } \\
\text { CD25, KLRG1 }\end{array}$ & $\begin{array}{l}\text { EOMES } \\
\text { T-bet }\end{array}$ & $\begin{array}{r}\text { IFN- } \gamma \\
\text { TNF }\end{array}$ \\
\hline & ieILC1 & $\begin{array}{l}\text { CD122, CD90, NK1.1, } \\
\text { NKG2A, NKp46, } \\
\text { IL-12RB1 }\end{array}$ & $\begin{array}{l}\text { EOMES } \\
\text { T-bet }\end{array}$ & $\begin{array}{l}\text { CD122, NKG2A, NKp46, } \\
\text { NKp44, IL-12RB1 }\end{array}$ & $\begin{array}{l}\text { EOMES } \\
\text { T-bet }\end{array}$ & IFN- $\gamma$ \\
\hline & ILC1 & $\begin{array}{l}\text { CD127, CD122, CD90, } \\
\text { CD49a, NK1.1, NKp46, } \\
\text { IL-12RB1 }\end{array}$ & T-bet & $\begin{array}{l}\text { CD127, CD161, } \\
\text { IL-12RB1, KLRG1, } \\
\text { ICOS, CD } 4^{+/-}\end{array}$ & T-bet & $\begin{array}{l}\text { IFN- } \gamma \\
\text { TNF }\end{array}$ \\
\hline 2 & ILC2 & $\begin{array}{l}\text { CD127, CD90, CRTH2, } \\
\text { CD117 }{ }^{+/-}, \text {CD25, ST2, } \\
\text { TSLPR, IL-17RB, } \\
\text { KLRG1, ICOS, MHCII }\end{array}$ & GATA3 & $\begin{array}{l}\text { CD127, CD161, CRTH2, } \\
\text { CD117 }{ }^{+/-}, \text {CD25, ST2, } \\
\text { TSLPR, IL17RB, } \\
\text { KLRG1, ICOS, CCR6, } \\
\text { MHCII }\end{array}$ & GATA3 & $\begin{array}{l}\text { IL-4, IL-5, } \\
\text { IL-9, } \\
\text { IL-13 }\end{array}$ \\
\hline \multirow[t]{3}{*}{3} & ILC3 $\mathrm{NCR}^{+}$ & $\begin{array}{l}\text { CD127, CD90, CD117, } \\
\text { NKp46, CD25, ICOS, } \\
\text { IL-23R, L-1R1 }\end{array}$ & $\begin{array}{l}\text { ROR } \gamma \mathrm{t} \\
\text { T-bet }\end{array}$ & $\begin{array}{l}\text { CD127, CD161, CD117, } \\
\text { NKp46, NKp44, } \\
\text { IL-12RB1, CD25, ICOS, } \\
\text { CCR6, IL-23R, IL-1R1, } \\
\text { MHCII }\end{array}$ & $\mathrm{ROR} \gamma \mathrm{t}$ & IL-22 \\
\hline & ILC3 NCR ${ }^{-}$ & $\begin{array}{l}\text { CD127, CD90, CD25, } \\
\text { ICOS, IL-23R, IL-1R1, } \\
\text { MHCII }\end{array}$ & $\begin{array}{l}\text { ROR } \gamma \mathrm{t} \\
\text { T-bet }\end{array}$ & $\begin{array}{l}\text { CD127, CD161, CD117, } \\
\text { IL-12RB1, CD25, ICOS, } \\
\text { CCR6, IL-23R, IL-1R1 }\end{array}$ & $\mathrm{ROR} \gamma \mathrm{t}$ & IL-17A \\
\hline & $\mathrm{LTi}$ & $\begin{array}{l}\text { CD127, CD90, CD117, } \\
\text { CD25, CCR6, IL-23R, } \\
\text { IL-1R1, MCHII, } \\
\text { CD4 }{ }^{+/-}, \text {NRP1 }\end{array}$ & $\mathrm{ROR} \gamma \mathrm{t}$ & $\begin{array}{l}\text { CD127, CD161, CD117, } \\
\text { CD25, CCR6, IL-23R, } \\
\text { IL-1R1, NRP1 }\end{array}$ & $\mathrm{ROR} \gamma \mathrm{t}$ & $\begin{array}{r}\text { IL-17A, } \\
\text { IL-22 }\end{array}$ \\
\hline
\end{tabular}

ICOS, Inducible T-cell costimulator; KLRG1, killer cell lectin-like receptor subfamily G member 1; NCR, natural cytotoxicity receptor; GATA3, GATA-binding factor 3; EOMES, eomesodermin; TSLPR, thymic stromal lymphopoietin receptor; TFs; transcription factors; IFN, interferon; TNF, tumor necrosis factor; IL, interleukin; ROR $\gamma \mathrm{t}$, RAR-related orphan receptor $\gamma \mathrm{t}$. 
Innate Lymphoid Cells as Cytokine Hubs

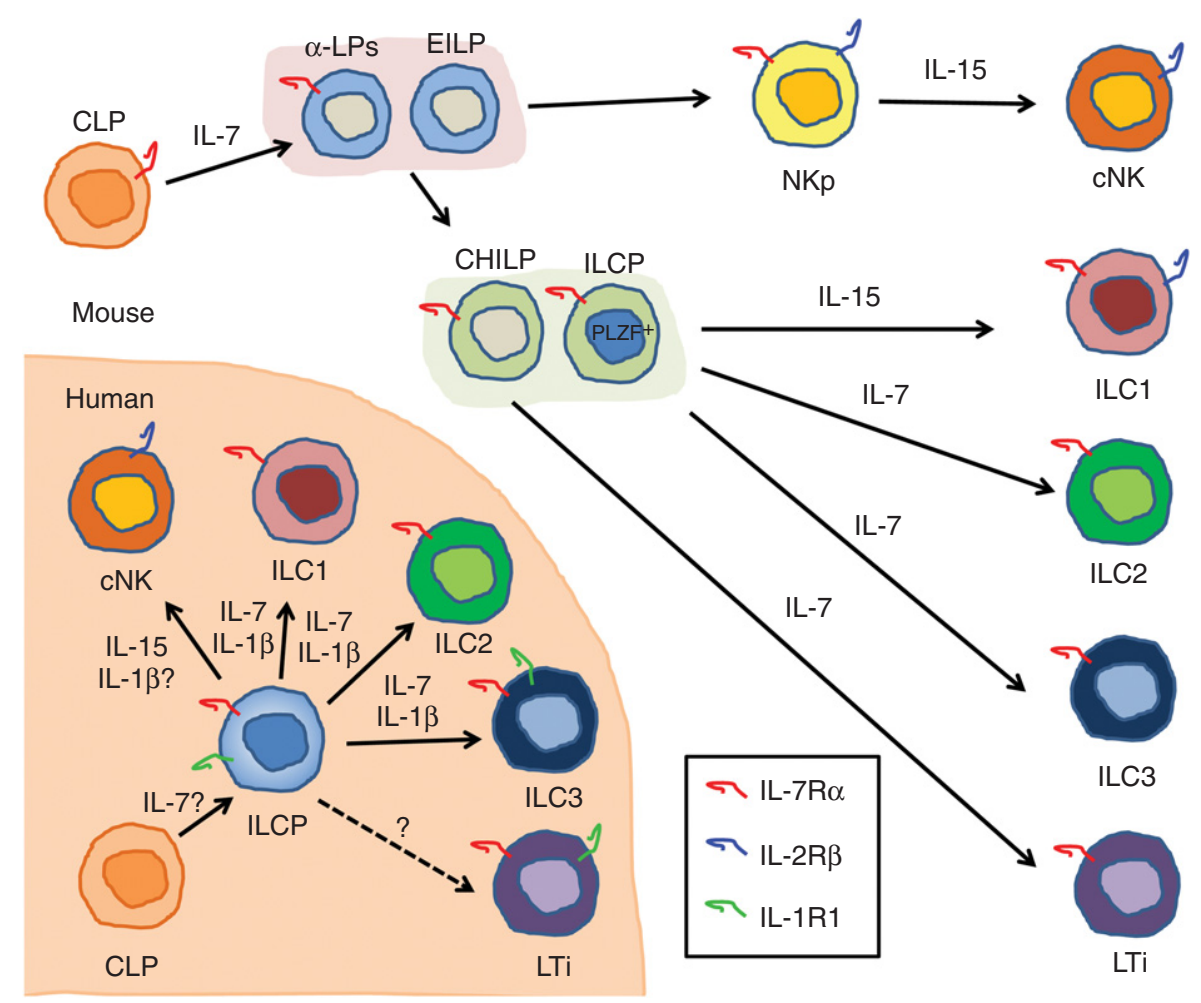

Figure 1. Cytokines involved in mouse and human innate lymphoid cells (ILCs) development. All ILCs are derived from a common lymphoid progenitor (CLP). In the mouse, interleukin (IL)-7 is essential for the development of ILC2, ILC3, and lymphoid tissue inducer (LTi) cells, and IL-15 is required for development of natural killer (NK) cells. IL-15 is important for ILC1 development but some ILC1 can develop independent of IL-15. For humans, IL-7 and IL-15 also play an important role in ILC and NK-cell development, and some studies indicate the involvement of IL-1 $\beta$ as, thus far, identified ILC progenitors (ILCPs) all express its receptor. $\alpha$-LP, $\alpha$-Lymphoid progenitor; EILP, early innate lymphoid progenitor; CHILP, common helperlike ILC progenitor; PLZF, promyelocytic leukemia zinc-finger protein; NKp, NK progenitor; cNK, conventional NK.

from the CLP, which resides in the bone marrow (Possot et al. 2011; Hoyler et al. 2012). CLPs further develop into progenitors expressing the $\alpha 4 \beta 7$ integrin (called $\alpha$ lymphoid progenitors $[\alpha-\mathrm{LPs}])$ and the early innate lymphoid progenitors (EILPs) that are able to produce NK cells and all helper ILCs but have lost the potential to differentiate into B and T cells (Yu et al. 2014; Yang et al. 2015). $\alpha$-LPs and EILPs develop into the common helper-like ILC progenitors (CHILPs) able to differentiate into all helper ILC subsets, including LTi cells, but not into NK cells (Klose et al. 2014). The CHILP population contains a subset of cells expressing promyelocytic leukemia zinc-finger protein (PLZF), so-called ILC progenitors (ILCPs), which have lost the potential to develop into LTi cells but retain the ability to generate helper ILCs (Constantinides et al. 2014). ILC development is dependent on the expression of the common cytokine receptor $\gamma c$, which is shared by the IL-2, IL-4, IL-7, IL-9, IL-15, and IL-21 receptors (Rochman et al. 2009). IL-7 and IL-15 are the $\gamma c$ family cytokines that are important for ILC development. NK cells express IL-2/IL-15R $\beta$ chain (IL-2R $\beta$ or CD122) and IL-15R $\alpha$ but not IL-7R $\alpha$ chain (or CD127), and their development and/ or maintenance is dependent on IL-15 (Kennedy et al. 2000), whereas all helper ILCs express IL-7R $\alpha$ and particularly ILC2s and ILC3s re- 
M. Nagasawa et al.

quire IL-7 for their development and/or maintenance (Moro et al. 2010; Neill et al. 2010; Vonarbourg et al. 2010; Hoyler et al. 2012). Recently, however, it was reported that functional ILC2s and ILC3s are present in the lamina propria but not in other organs of $17 \mathrm{ra}^{-/-}$mice, indicating that the requirement for IL-7R is incomplete. IL-15 could sustain these IL-7R-independent ILC2s and ILC3s (Robinette et al. 2017). IL-7R $\alpha$ and IL-2R $\beta$ are expressed on ILC1s, but IL-7 signaling is not required for their development and maintenance because mice lacking IL-7R $\alpha$ displayed normal ILC1 development. In contrast, ILC1 cell numbers were significantly reduced in IL-15-deficient mice but not absent, suggesting that ILC1 development partially relies on additional factor(s) besides IL-15 (Klose et al. 2014).

ILC development depends on the transcriptional regulator, inhibitor of DNA-binding 2 (Id2), as Id2 deficiency leads to developmental block of all ILCs (Yokota et al. 1999; Boos et al. 2007; Moro et al. 2010). Id 2 expression in CHILPs is controlled by the basic leucine zipper transcription factor NFIL3, promoting CHILP commitment toward ILCp and facilitating the development of ILC1s, ILC2s, and ILC3s (Yu et al. 2014; Xu et al. 2015). NFIL3 expression is controlled by IL-7/signal transducers and activators of transcription (STAT) 5 signaling. Indeed, IL-7 and IL-15 are differentially required by ILC subsets, governing their differentiation and/or survival. Thus, CHILPs as well as ILCPs are characterized by their expression of Id 2 and give rise to various ILC subsets, whereas NK cells develop from Id2-negative CLPs and require IL-15 signaling (Diefenbach et al. 2014; Huntington 2014; Klose et al. 2014).

The intermediate cellular stages of human ILC development are less clear than those in mice (Fig. 1). An IL- $1 \mathrm{R} 1^{+} \mathrm{CD} 34^{+} \mathrm{ROR} \gamma \mathrm{t}^{+}$hematopoietic progenitor cell (HPC) was found in tonsil and intestinal lamina propia that gives rise to ILC3s (Montaldo et al. 2014), but another study showed that a similar population of $\mathrm{Lin}^{-} \mathrm{CD} 34^{+} \mathrm{CD} 45 \mathrm{RA}^{+} \mathrm{CD} 117^{+} \mathrm{IL}-1 \mathrm{R} 1^{+}$in secondary lymphoid tissues could develop into all ILC subsets, including NK cells (Scoville et al. 2016). Most recently, $\mathrm{Lin}^{-} \mathrm{CD} 127^{+} \mathrm{CD} 117^{+} \mathrm{IL}-$
$1 \mathrm{R} 1^{+}$ILC precursors were found in the peripheral tissues and circulation, which could generate all ILC subsets (Lim et al. 2017). These ILC precursors may be the innate version of naïve $T$ cells that can develop into all Th cell subsets under the influence of cytokines. Also, in humans, ILC development depends on $\gamma$ c because patients who are deficient in this receptor (i.e., patients with X-linked severe combined immunodeficiency [XSCID]) lack helper ILC and NK cells (Vely et al. 2016). In one study, it was shown that IL7R-deficient SCID patients lack ILC3s (Vonarbourg et al. 2010), indicating that, like in mice, human ILC3s require IL-7 for development. It is to be expected that patients with XSCID also have diminished ILC1s and ILC2s but this has yet to be reported.

\section{CYTOKINES: THE INS AND OUTS OF ILCS}

\section{Group 1 ILCs}

Group 1 ILCs include NK cells and ILC1s (Table 1). These cell types are distinct because their developmental trajectories are different (Constantinides et al. 2014; Klose et al. 2014) Whereas NK cells are dedicated cytotoxic cells expressing cytotoxic molecules like perforin and granzymes, ILC1s are in general noncytotoxic, although ILC1 subsets with weak cytotoxic activity have been described. This might be comparable with Th1 cells that under certain conditions mediate cytotoxic activity as well. In naïve mice, ILC1 express CD127, CD49a, and the transcription factor T-bet but not the related factor Eomes, whereas NK cells lack CD127 and express Eomes and CD49b. However, as reviewed (Spits et al. 2016), it is difficult to unambiguously distinguish ILC1s from NK cells, particularly in mice with ongoing immune responses.

ILC1s produce IFN- $\gamma$ and tumor necrosis factor (TNF) (Fig. 2) (Vonarbourg et al. 2010; Bernink et al. 2013; Fuchs et al. 2013; Daussy et al. 2014; Klose et al. 2014). Like NK cells, ILC1s are activated by IL-12, IL-18, and IL-15 (Satoh-Takayama et al. 2009; Fuchs et al. 2013), IL-12 and IL-18 are produced by monocytes and dendritic cells (DCs) activated during infections (Kang et al. 2008), whereas IL-15 is expressed 

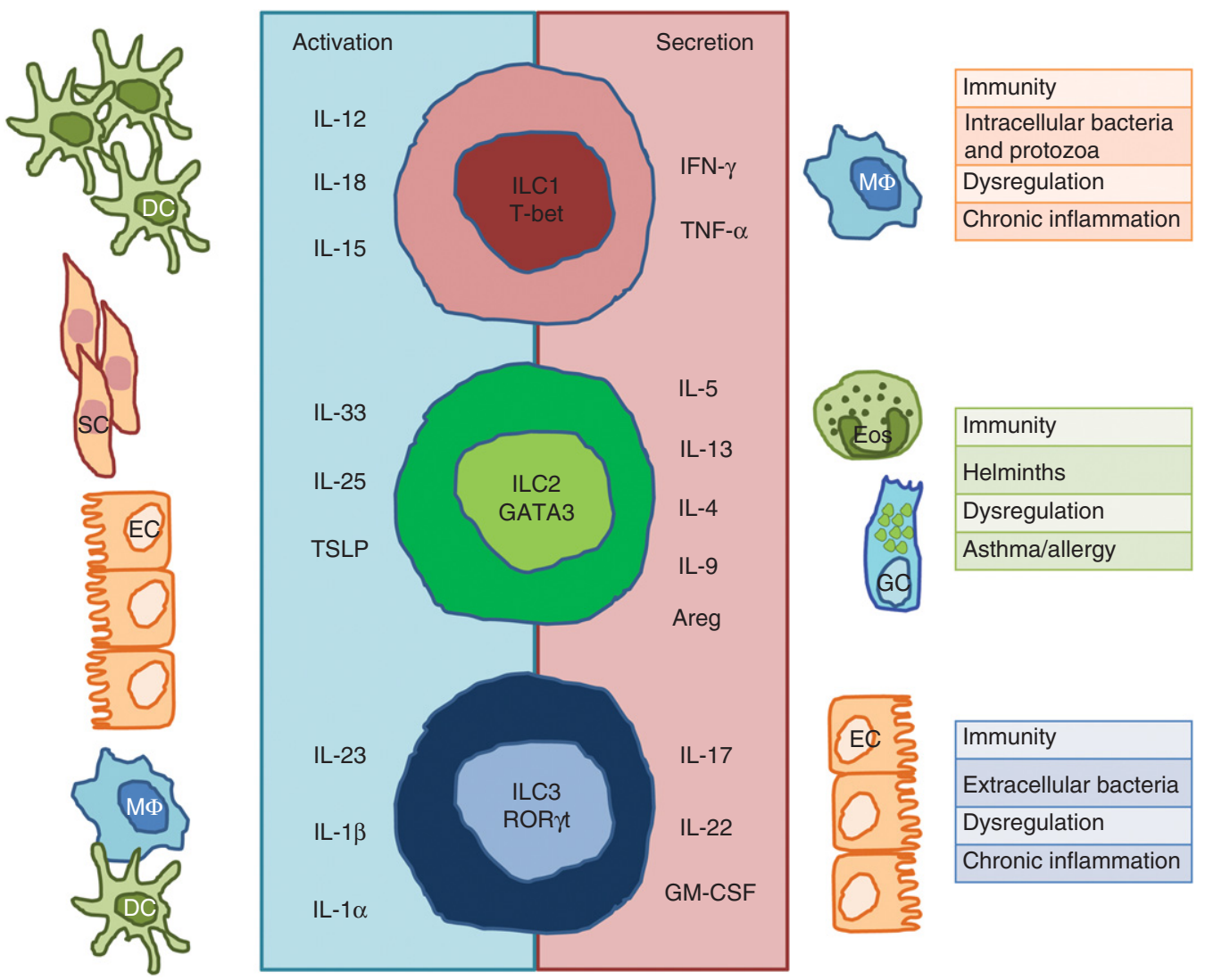

Figure 2. Innate lymphoid cell (ILC) subsets and cytokines. ILC1s depend on transcription factor T-bet for their function and produce interferon (IFN)- $\gamma$ and tumor necrosis factor (TNF)- $\alpha$ in response to interleukin (IL)-12, IL-15, and IL-18 derived from dendritic cells (DCs). ILC2s require GATA3 and are endowed with the ability to secrete IL-4, IL-5, IL-9, IL-13, and amphiregulin (Areg) in response to IL-25, IL-33, and thymic stromal lymphopoietin (TSLP) derived from epithelial cells and tissue-resident immune cells. ILC3s depend on the transcription factor RAR-related orphan receptor $\gamma \mathrm{t}$ (ROR $\gamma \mathrm{t}$ ) and secrete IL-17, IL-22, and granulocyte macrophage colony-stimulating factor (GM-CSF) in response to IL-23, IL-1 $\beta$, and IL- $1 \alpha$ derived from macrophages and DCs. ILC immune responses are shaped to cope with different types of pathogens, although their dysregulation might lead to chronic inflammation. SC, Stromal cell; EC, epithelial cell; Eos, eosinophils; GC, goblet cell.

not only by activated monocytes and macrophages, but also by a wide variety of tissues, including placenta, skeletal muscle, kidney, epithelial, and fibroblast cell lines, which describe its pleiotropic function (Grabstein et al. 1994). IFN- $\gamma$ plays a crucial role in innate and adaptive immunity against viral and intracellular bacterial infections by inhibiting viral replication directly and promoting macrophage activation, which increases phagocytosis and directly or indirectly up-regulates both major histocompatibility complex (MHC) class I and class II an- tigen presentation (Schoenborn and Wilson 2007). ILC1s accumulate in a variety of inflammatory diseases, including Crohn's disease, and the resulting increased levels of IFN- $\gamma$ production may contribute to chronical intestinal inflammation such as IBD (Bernink et al. 2013; Fuchs et al. 2013).

\section{Group 2 ILCs}

Both in human and mouse, ILC2s are characterized by their high expression of transcription 
M. Nagasawa et al.

factor GATA3, which is crucial for their ability to produce the Th2 type of cytokines IL-4, IL-5, and IL-13 (Hoyler et al. 2012; Mjosberg et al. 2012). Mouse ILC2s can be identified by the combined expression of IL-7R $\alpha$, CD25, CD90, SCA-1, ICOS, and KLRG1, but they lack the lineage markers CD3, B220, CD11b, Ter119, and Gr-1 (Moro et al. 2010; Neill et al. 2010; Price et al. 2010), and NK1.1 and NKp46, which are expressed on part of the ILC3s and ILC1s. In humans, ILC2s uniformly express IL-7R $\alpha$, CD161, CRTH2, and CD25 (Table 1) (Mjosberg et al. 2011, 2012; Monticelli et al. 2011).

ILC2s produce IL- 5 and IL-13 in response to IL-33, IL-25, or both IL-33 and IL-25 (Moro et al. 2010; Neill et al. 2010; Price et al. 2010), and TSLP enhances production of those cytokines (Fig. 2) (Kim et al. 2013). ILC2-activated cytokines are produced by many cell types. IL33 is constitutively expressed in airway epithelial cells and its expression can be induced in keratinocytes, endothelial cells, fibroblast, smooth muscle cells, macrophages, and DCs on stimulation (Schmitz et al. 2005; Carriere et al. 2007). TSLP is primarily expressed by epithelial cells and keratinocytes in the skin, gut, and lungs (Reche et al. 2001), and involved in the regulation of type 2 cytokine-driven inflammatory processes occurring at the barrier surface (West et al. 2012; Ziegler 2012). IL-25 is produced by activated Th2 cells, macrophages, mast cells, eosinophils, basophils, lung, intestinal, and skin epithelial cells, and endothelial cell fibroblasts (Fort et al. 2001; Zaph et al. 2008; Valizadeh et al. 2015). More recently, specialized cell types within the epithelial layer of the intestine, called Tuft cells, were found to produce IL-25 (von Moltke et al. 2016).

Recently, the existence of a second ILC2 subtype was reported, which was called inflammatory ILC2 (iILC2). iILC2s appear in vivo on injection into mice of IL-25 and were distinct from IL-33-responsive natural ILC2 (nILC2) (Huang et al. 2015). Like nILC2s, ilLC2s contribute to expulsion of the parasite Nippostrongylus brasiliensis by producing IL-13 but they also partially protect mice against the fungus Candida albicans by producing IL-17. Because ilLC2s can develop into nILC2s in vivo and in vitro, it was speculated that iILC2s are a transient precursor that arises on inflammation. However, it is as-yet unknown from which precursor ilLC2s develop.

IL-5, produced by ILC2s, plays a crucial role in the development, activation, and survival of eosinophils (Lopez et al. 1988; Yamaguchi et al. 1988; Dent et al. 1990; Kopf et al. 1996). Eosinophils are implicated in the pathogenesis of variable inflammatory processes, including helminth, bacterial, and viral infections, tissue injury, tumor immunity, and allergic diseases (Hogan et al. 2008). IL-13 has both pro- and anti-inflammatory effects, depending on the target cells (Wynn 2003), and its role in mucosal immunology is particularly well appreciated. For instance, IL-13 induces hyperplasia and mucus production by goblet cells and production of the eosinophils chemoattractant eotaxin by epithelial cells (Grunig et al. 1998; Zhu et al. 1999; Pope et al. 2001; Mishra and Rothenberg 2003). Consistent with these reports, ILC2s derived IL-13 induce mucus production, helminth expulsion, eotaxin production, eosinophil recruitment, airway hyperreactivity, and pulmonary fibrosis (Schmitz et al. 2005; Bhandoola and Sambandam 2006; Kang et al. 2008; Rochman et al. 2009; Diefenbach et al. 2014; Roediger et al. 2015).

Activation of ILC2s is regulated by cytokines produced by ILC2s, including IL-4 and IL-9. Although ILC2s are able to produce IL-4 in vitro (Moro et al. 2010; Barlow et al. 2012; Mjosberg et al. 2012; Salimi et al. 2013), there is little evidence that IL-4 is secreted in vivo during steady-state or helminth infection (Price et al. 2010; Liang et al. 2011; Roediger et al. 2015), suggesting that production of IL-4, IL-5, and IL-13 are regulated differentially. This notion is consistent with the observations that Leukotriene D4 promotes calcium signaling, NFAT activation, and IL-4 secretion (Doherty et al. 2013), and that prostaglandin D2 (PGD2), which interacts with CRTH2 and triggers mobilization and enhancement of NFAT, induced a massive production of IL-4 (Xue et al. 2014). These findings indicate that IL-4 requires an additional NFAT-activating signal to be efficiently produced. IL- 4 is an autocrine factor not only produced by ILC2s but also able to 
Innate Lymphoid Cells as Cytokine Hubs

coactivate these cells. IL-4 acts in synergy with IL-33 to induce ILC2 proliferation and production of IL-5 and IL-13, although IL-4 by itself was insufficient to induce production of IL-5 and IL-13. Basophils and eosinophils cross talk with ILC2s by producing IL-4, which enhances the activities of ILC2s. Recently, we showed the existence of a positive feedback loop in the interaction of ILC2s and eosinophils; IL-4 produced by eosinophils coactivates ILC2s to produce IL-5, which activates eosinophils (Bal et al. 2016). This positive feedback loop may play a role in the inflammatory airway disease chronic rhinosinusitis (CRS). In the inflamed nasal polyps of CRS patients, eosinophils colocalize with ILC2 (Bal et al. 2016).

ILC2s are predominant producers of IL-9 (Wilhelm et al. 2011; Licona-Limon et al. 2013). IL-9 fate reporter mice infected with $N$. brasiliensis displayed a higher IL- 9 expression in lung ILC2s when compared to T cells. Interestingly, IL-9R, a member of the $\gamma c$ receptor family, is expressed by ILC2s at much higher levels than by $\mathrm{T}$ cells (Price et al. 2010). Turner et al. (2013) showed that Il9r-deficient mice infected with $N$. brasiliensis showed a reduced number of ILC2s and impaired production of IL-13, IL-5, and amphiregulin, resulting in a reduction of eosinophil recruitment, delay of worm expulsion, and diminished tissue repair. In line with this study, it has been shown that IL9 acts in an autocrine fashion on ILC2s, enhancing the production of IL-5 and IL-13 in papaininduced airway inflammation (Wilhelm et al. 2011). Furthermore, the IL-9 signal was crucial for the survival of activated ILC2s, which was mediated by the antiapoptotic protein BCL2 (Turner et al. 2013). Interestingly, IL-9 production seems to be differently regulated than IL-5 and IL-13. In lung ILC2s stimulated with IL-33, IL-9 was up-regulated in T-bet-deficient mice without affecting IL-5 and IL-13, suggesting that T-bet mainly suppresses IL-9 production (Matsuki et al. 2017). Furthermore, the expression of IL-9 in ILC2 seems to be transient (Wilhelm et al. 2011; Licona-Limon et al. 2013), indicative of a tighter regulated expression. Multiple other molecules, including IRF4, transforming growth factor (TGF)- $\beta$, Itk, or STAT6 regulate IL-9 expression in T cells (Jabeen and Kaplan 2012; Yao et al. 2013). Of these, IRF4 modulates IL-9 secretion by ILC2s (Mohapatra et al. 2016). However, there are also differences between factors that trigger IL-9 secretion by $\mathrm{T}$ cells and ILCs. For example, IL-25 stimulates IL9 production by $\mathrm{T}$ cells (Angkasekwinai et al. 2010) but has no effect on IL-9 production by ILC2s (Wilhelm et al. 2011).

IL-9 produced by mucosal ILC2s enhances mucus production in goblet cells and activates mast cells in inflammatory lung diseases (Jabeen and Kaplan 2012; Ealey et al. 2017). Consistent with this, blocking IL-9 in chronic models of lung inflammation inhibits mastocytosis and airway remodeling (Kearley et al. 2011). Similarly, in cystic fibrosis, a disease characterized by high levels of IL-9, ILC2s play a key role in promoting lung inflammation (Moretti et al. 2017). All of these studies highlight the relevance of IL-9 as autocrine cytokine acting as a promotor of ILC2 function involved in pathogens removal, tissue repair in the recovery phase of lung inflammation, as well as their key role in chronic lung inflammatory diseases (Fig. 3).

Cytokines can also negatively regulate cytokine secretion by ILC2. Type I and II IFNs have been shown to inhibit the secretion of signature cytokines by ILC2s in a manner dependent on the ISGF3 complex (STAT1, STAT2, and IRF9) for type I IFNs or STAT1 activation for type II IFN- $\gamma$ (Molofsky et al. 2015; Duerr et al. 2016; Moro et al. 2016). In addition, IL-27, a member of the IL-12/23 family of cytokines, can inhibit ILC2 cytokine secretion and ILC2-mediated pathology via STAT1 (Duerr et al. 2016; Moro et al. 2016).

\section{Group 3 ILCs}

Group 3 ILCs are dependent on transcription factor RAR-ROR $\gamma \mathrm{t}$ and comprise a heterogeneous population of ILC3s and LTi cells (Cella et al. 2009; Cupedo et al. 2009; Artis and Spits 2015). In mouse, three subsets of ILC3s can be distinguished based on the cell-surface expression of chemokine receptors NKp46 and CCR6. $\mathrm{CCR}^{+}{ }^{+} \mathrm{ILC}_{3}$ s comprise $\mathrm{CD} 4^{+}$and $\mathrm{CD}^{-}{ }^{-} \mathrm{LTi}$ cells (Mebius et al. 1997; Eberl et al. 2004; 
M. Nagasawa et al.

A ILC1

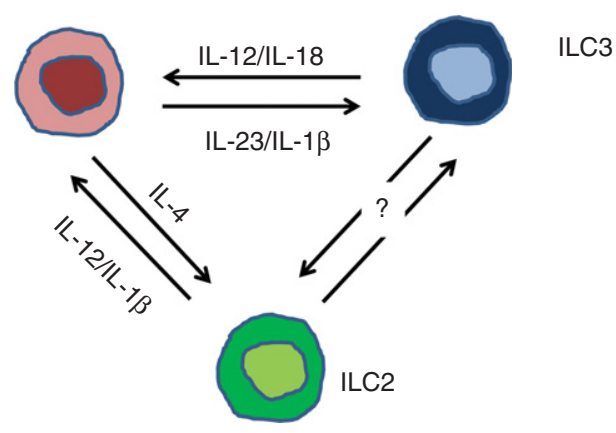

B

Signal 1: IL-1 family (epithelial stress/damage)

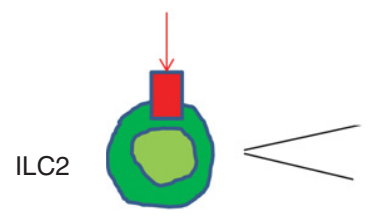

Signal 2:

(pathogen dependent) ILC1
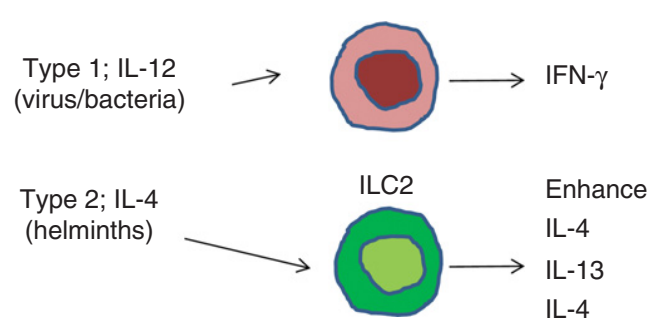

Figure 3. Innate lymphoid cell (ILC) plasticity is governed by the cytokine milieu. ILCs can switch between fully polarized subsets to rapidly adapt to changes occurring in their environment. (A) Interleukin (IL)-12 and IL-18 drives the transdifferentiation of ILC3s into ILC1s. This process is reversible because ILC1s convert to ILC3s in the presence of IL- 23 and IL-1 $\beta$. ILC2s undergo cell plasticity in the presence of IL- $1 \beta$ and IL- 12 to convert into interferon (IFN)- $\gamma$-secreting ILC1s. IL-4 can revert this transdifferentiation process and convert ILC1s into ILC2s. (B) Double hit model of ILC2s plasticity. ILC2s require of two types of signals to undergo transdifferentiation. Signal 1, secreted by epithelial cells on stress or damage conditions, is induced by IL-1 family members and trigger modifications in the chromatin architecture. DNA reprogramming will be orchestrated by the signal 2 or "driving cytokines." IL-12 drives ILC2s plasticity toward ILC1s to better cope with intracellular bacteria or virus, whereas IL-4 enhances type 2 immune responses against helminths.

Sawa et al. 2010; van de Pavert et al. 2014), and CCR6 $^{-}$ILC3s can be divided into two subsets based on the presence or absence of the natural cytotoxicity receptor (NCR) NKp46 (Table 1) (Artis and Spits 2015). Human ILC3s express CD117 (also known as c-Kit) and two subsets can be defined by their expression of NKp44 (Hoorweg et al. 2012; Hazenberg and Spits 2014). Almost all human ILC subsets express CCR6 (Mjosberg et al. 2011; Hazenberg and Spits 2014; Shikhagaie et al. 2017); therefore, CCR6 expression does not define human LTi cells. However, neuropilin 1 (NRP1, also known as CD304 or BDCA4) was exclusively found on ILC3s isolated from lymphoid tissues but not from peripheral blood or skin, and $\mathrm{NRP} 1^{+}$
ILC3 had LTi activity in vitro (Shikhagaie et al. 2017). Nrp1 transcripts were found on mouse LTi cells isolated from adult intestine (Robinette et al. 2015). Together, these findings indicate that NRP1 is a conserved marker for LTi cells.

Whereas IL-2 and IL-7 maintain cell survival and proliferation of ILC3 subsets, ILC3s are activated by IL- $1 \alpha$, IL- $1 \beta$, and IL-23 to produce IL-22, IL-17A, IL-17F, and granulocyte macrophage colony-stimulating factor (GMCSF) (Fig. 2). The combination of IL-1 $\beta$ and IL-23 are particularly efficient in inducing the cytokine production by ILC3s (Zheng et al. 2008; Cella et al. 2009, 2010; Takatori et al. 2009; Hughes et al. 2010; Kim et al. 2014; Longman et al. 2014; Hernandez et al. 2015). IL-1 $\beta$ 
Innate Lymphoid Cells as Cytokine Hubs

and IL-23 are produced and secreted by DCs and macrophages in response to exogenous or endogenous signals (Lopez-Castejon and Brough 2011; Teng et al. 2015). In humans, IL-17 is predominantly produced by NKp44- ILC3s, whereas IL-22 is produced by NKp $44^{+}$ILC3s (Cupedo et al. 2009; Hoorweg et al. 2012). IL-17 and IL-22 are known to have distinct roles in inducing an innate response in epithelial cells, as IL-17 is responsible for inflammatory tissue responses and involved in several autoimmune diseases, whereas IL-22 is involved in tissue protection and repair (Ouyang and Valdez 2008; Eyerich et al. 2010). However, there are also reports suggesting that IL-22 can be involved in inflammatory diseases such as inflammatory bowel disease and psoriasis (Wolk et al. 2010; Maloy and Powrie 2011).

\section{CYTOKINES THAT MODULATE ILC PLASTICITY}

Th cell subsets often display plasticity, for example under certain conditions a Th17 cell can adopt features of Th1 cells (O'Shea and Paul 2010). Although ILCs were initially classified under stable phenotypes (ILC1/2 and ILC3s), it is now clear that they also show considerable plasticity (Fig. 3). Each ILC subset senses inductive cytokines (e.g., IL-25/TSLP/IL-33 activate ILC2s) that trigger their core transcriptional program, resulting in the secretion of signature cytokines (e.g., IL-5 secreted by ILC2s) tailored to combat specific microbial pathogens. However, ILCs are particularly sensitive for cell reprograming by certain cytokines ("switching cytokines"), which enable the cell to acquire other functions to better cope with changes in their microenvironment that require a different ILC response (Fig. 3A).

Early studies of Colonna and Cella provided the first indication of ILC plasticity, showing that IL-22-secreting-NCR ${ }^{+}$ILC3 activated with IL- $1 \beta$ and IL-23 induce the production of IL22 or IFN- $\gamma$, depending on whether these cells are cultured in IL-7 or IL-2 plus IL-7, respectively (Cella et al. 2010). Moreover, NCR ${ }^{+}$ILC3s $_{\text {s }}$ cultured with IL-2 plus IL-7 became responsive to IL-12, which might further promote IFN- $\gamma$ secretion and immunopathology. In addition, human IL-22-producing ILC3s can produce IL-2, IL-5, and IL-13 and IL-22 after activation of TLR2 ligands (Crellin et al. 2010). Together, these studies with human ILCs suggested that differential activation signals can change the cytokine-production pattern of ILC3s. Using mouse models, Vonarbourg et al. (2010) showed that IL-7 stabilize ROR $\gamma \mathrm{t}$ expression by IL-22producing $\mathrm{NCR}^{+}$ILC3s, whereas IL-12 and IL15 accelerate ROR $\gamma t$ loss accompanied with an acquisition of T-bet and the capacity to produce IFN- $\gamma$. IL-12 drives NCR ${ }^{+}$ILC3 into IFN- $\gamma$-producing-ILC1s by down-regulating ROR $\gamma$ t and up-regulating T-bet, a process that is enhanced in the presence of IL-18 and/or IL-1 $\beta$ (Vonarbourg et al. 2010). Human ILC3s were shown to convert into ILC1s under the influence of IL-1 $\beta$ and IL-12. Transdifferentiation of ILC3s into ILC1s is reversible because ILC1s convert to ILC 3 s in the presence of IL-23 and IL-1 $\beta$, a process accelerated by retinoic acid (Bernink et al. 2013, 2015). IL-12-producing CD14 ${ }^{+}$intestinal DCs switch ILC3s into IFN- $\gamma$-producing ILC1s, whereas conversely, retinoic acid and IL-23-producing $\mathrm{CD} 14^{-}$DCs induce the differentiation of ILC1s into ILC3s. ILC3 into ILC1 conversion probably occurs in inflammatory conditions in vivo, because an increased frequency of inflammatory ILC1s inversely correlates with the frequency of ILC3s in inflamed intestinal resection specimens from Crohn's disease patients (Bernink et al. 2013). A study using immunodeficient BALB/c mice with a human immune system confirmed that an intestinal inflammation resulted in a shift of ILC3s into ILC1s. Overall, these data support the idea that bidirectional ILC3, ILC1 plasticity is involved in the regulation of innate immunity in the gut mucosa.

ILC2s also show plasticity. IL-1 $\beta$ plays a key role in ILC2 transdifferentiation. IL- $1 \beta$ is a potent activator of ILC2s (Bal et al. 2016; Lim et al. 2016; Ohne et al. 2016; Silver et al. 2016), enhancing the expression of the receptors for the epithelial cytokines IL-33, IL-25, and TSLP and triggering IL-5 and IL-13 secretion. IL- $1 \beta$ also induces transcriptome changes, resulting in an induction of transcription of TBX1 and IL12RB2 in ILC2s, setting the stage for conver- 
M. Nagasawa et al.

sion into IFN- $\gamma$-secreting ILC1s in response to IL-12. IL-12RB1 is critical for the transdifferentiation because ILC2s from patients with biallelic mutations in the IL12RB1 gene did not acquire the capacity to produce IFN- $\gamma$ and lacked ILC1s (Lim et al. 2016). The combination of IL$1 \beta$ and IL-12 favor epigenetic modifications (increase of $\mathrm{H} 3 \mathrm{~K} 9 \mathrm{ac}$ and a decrease of $\mathrm{H} 3 \mathrm{~K} 27 \mathrm{me} 3$ at the IL12RB2 locus) that enhance IL12R 32 expression in ILC2s and perpetuate the acquisition of the ILC1 phenotype (Ohne et al. 2016). Interestingly, whereas IL- $1 \beta$ increases accessibility at the TBX21 and IFNG loci, the IL5 and IL13 loci remain accessible as well, which suggested that ILC2-derived ILC1s could differentiate back to ILC2s. Indeed, when ILC2-derived ILC1s were cultured with IL-4, these cells revert to ILC2s (Ohne et al. 2016). ILC2 plasticity might occur in the inflamed lungs of COPD patients that show an increase of ILC1 subsets, whereas the sizes of the ILC3 and ILC2 pools decrease (Bal et al. 2016). The proportion of ILC1s also increases in the peripheral blood of COPD patients, and the degree of this increase is correlated with disease severity (Silver et al. 2016).

The high degree of ILC plasticity raises the question as to the physiological relevance of this phenomenon. As ILCs are mostly tissue resident with a limited influx of cells from the periphery, plasticity enables ILC to quickly adapt to changing environments. For example, IL-22producing ILC3s representing most ILCs in a noninflamed gut can rapidly change into INF$\gamma$-producing ILC1s on inflammation to help neutralize pathogenic bacteria such as Salmonella enterica (Klose et al. 2013). After resolution of the infection, these ILC1s may revert to IL-22producing ILC3, restoring the homeostatic phenotype. ILC plasticity might be induced by IL- $1 \beta$ or equivalent factors (signal 1), whereas cytokines such as IL-12 determine the final outcome (signal 2) (Fig. 3B). This way, ILCs effectively tailor their immune response against pathogens.

\section{THE ROLE OF ILC-PRODUCED CYTOKINES IN TUMOR IMMUNITY}

Resident ILCs are among the first line of defense against pathogens and likewise ILCs might also establish the first cytokine dialog with the nascent tumor in the mucosa, promoting or inhibiting tumor growth. The tumor microenvironment may trigger tailored immune responses by ILC1s, ILC2s, and ILC3s. Along these lines, a novel ILC1-like cell expressing NK1.1, CD49a, CD103, Granzyme, and TNF-related apoptosisinducing ligand (TRAIL) with strong antitumor potential has been identified in mice. These cells may play a key role in immune surveillance of tumors (Dadi et al. 2016).

Colorectal cancer (CRC) tissues show high levels of IL-17A, IL-17F, and IL-22 as well as the Th17-polarizing cytokines IL-1 $\beta$, IL-6, IL-21, and TGF- $\beta$ (West et al. 2015). The abundance of several of these cytokines correlate with the disease stage (West et al. 2015). Collectively, these cytokines promote tumor growth and proliferation, resistance to apoptosis, angiogenesis, gene instability, invasiveness, and metastasis. Interestingly, ILC3s, the major ILC subset in the gut, has been shown to promote tumor growth in a mouse model of bacteria-induced CRC in an IL-22-dependent manner (Kirchberger et al. 2013). Depletion of ILC3s protect mice from IBD-associated CRC. Blocking IL-17 did not did not prevent tumor formation, whereas blocking IL-22 decreases tumor burden. Although IL-22 transgenic mice do not display a clear increase of spontaneous tumors (Park et al. 2011; Sabat et al. 2014), formation a carcinogen-induced hepatocellular carcinoma was enhanced in IL-22 transgenic mice, whereas tumor formation was reduced in IL-22-deficient mice (Sabat et al. 2014). In line with these studies, deficiencies in IL22BP, a natural neutralizing molecule of IL-22, increase the tumor burden in IBD-associated CRC (Huber et al. 2012). These observations suggest that IL-22 acts to accelerate the development of ongoing inflammation-induced tumors.

IL-12 that mediated the repression of subcutaneous melanoma (transplantation of B16 melanoma cell line into $\mathrm{C} 57 \mathrm{BL} / 6$ mice) was independent of adaptive immunity, NK T cells, or NK cells. Instead, the crucial antitumor activity was mediated by NKp $46^{+}$ILC3, which differentiated into IFN- $\gamma$-secreting ILC1 apparently induced by IL-12. The mechanism of tumor rejec- 
Innate Lymphoid Cells as Cytokine Hubs

tion is unclear. Tumor rejection did not involve IFN- $\gamma$ or other analyzed ILC-secreting cytokines (Eisenring et al. 2010).

In a mouse model of melanoma, which the tumor cells (B16F10) metastasize into the lung, the numbers of innate IL-5-producing cells were increased in response to tumor invasion. Furthermore, eosinophils, which possess antitumor activities, were located around the melanoma clusters set in the capillary vessels of alveolar walls. The key effect of IL- 5 was revealed in analyses of the antitumor response in IL-5- and IL5R-deficient mice or following treatment with blocking anti-IL-5 antibodies. In the absence of IL-5, increased tumor metastasis and reduced numbers of eosinophils in the lung were observed, suggesting that in this model eosinophil recruitment by ILC2s is critical to suppress tumor metastasis (Ikutani et al. 2012).

\section{FUTURE PERSPECTIVES}

Over the past decade, ILCs have emerged as important regulators of tissue homeostasis and innate immune responses. ILCs form a first line of defense against infectious pathogens, providing protection before the adaptive immune system is mobilized. ILCs may also amplify ongoing immune responses. As discussed here, cytokines play critical roles in mediating the functional activities of ILCs, serving as activators as well as effector molecules. ILC responses induced by cytokines need to be tightly regulated to prevent an uncontrolled cytokine storm. Although certain cytokines have been identified that inhibit ILC activation, the mechanisms of ILC control are incompletely understood. Some cytokines by themselves do not activate ILCs but either amplify or inhibit secretion of signature cytokines; the mechanisms for this are yet to be elucidated. ILCs also display plasticity, changing completely their cytokine-production profile on cues provided by their microenvironment. Plasticity has been observed in various inflammatory and metabolic diseases but it is yet unclear whether ILC plasticity is involved in causing a disease or amplifying the pathology or is merely a consequence of the disease process. Understanding the contribution of ILC plasticity to diseases requires relevant mouse models in which plasticity can be manipulated by genetic modification specifically in ILCs. This is quite a challenge because it is difficult to selectively target ILCs in the presence of an intact adaptive immune system. Such models may help us to investigate whether small molecular compounds or biologicals that modify the functions of ILCs are efficacious as therapeutics.

\section{ACKNOWLEDGMENTS}

H.S. is supported by an advanced grant of the European Research Council (ERC) (No. 341038).

\section{REFERENCES}

Angkasekwinai P, Chang SH, Thapa M, Watarai H, Dong C. 2010. Regulation of IL-9 expression by IL-25 signaling. Nat Immunol 11: 250-256.

Artis D, Spits H. 2015. The biology of innate lymphoid cells. Nature 517: 293-301.

Bal SM, Bernink JH, Nagasawa M, Groot J, Shikhagaie MM, Golebski K, van Drunen CM, Lutter R, Jonkers RE, Hombrink P, et al. 2016. IL-1 $\beta$, IL-4 and IL-12 control the fate of group 2 innate lymphoid cells in human airway inflammation in the lungs. Nat Immunol 17: 636-645.

Barlow JL, Bellosi A, Hardman CS, Drynan LF, Wong SH, Cruickshank JP, McKenzie AN. 2012. Innate IL-13-producing nuocytes arise during allergic lung inflammation and contribute to airways hyperreactivity. J Allergy Clin Immunol 129: 191-198, e191-e194.

Bernink JH, Peters CP, Munneke M, te Velde AA, Meijer SL, Weijer K, Hreggvidsdottir HS, Heinsbroek SE, Legrand N, Buskens CJ, et al. 2013. Human type 1 innate lymphoid cells accumulate in inflamed mucosal tissues. Nat Immunol 14: 221-229.

Bernink JH, Krabbendam L, Germar K, de Jong E, Gronke K, Kofoed-Nielsen M, Munneke JM, Hazenberg MD, Villaudy J, Buskens CJ, et al. 2015. Interleukin-12 and -23 control plasticity of $\mathrm{CD} 127^{+}$group 1 and group 3 innate lymphoid cells in the intestinal lamina propria. Immunity 43: $146-160$.

Bhandoola A, Sambandam A. 2006. From stem cell to T cell: One route or many? Nat Rev Immunol 6: 117-126.

Boos MD, Yokota Y, Eberl G, Kee BL. 2007. Mature natural killer cell and lymphoid tissue-inducing cell development requires Id2-mediated suppression of E protein activity. $J$ Exp Med 204: 1119-1130.

Carriere V, Roussel L, Ortega N, Lacorre DA, Americh L, Aguilar L, Bouche G, Girard JP. 2007. IL-33, the IL-1-like cytokine ligand for ST2 receptor, is a chromatin-associated nuclear factor in vivo. Proc Natl Acad Sci 104: 282287.

Cella M, Fuchs A, Vermi W, Facchetti F, Otero K, Lennerz JK, Doherty JM, Mills JC, Colonna M. 2009. A human 
M. Nagasawa et al.

natural killer cell subset provides an innate source of IL-22 for mucosal immunity. Nature 457: 722-725.

Cella M, Otero K, Colonna M. 2010. Expansion of human NK-22 cells with IL-7, IL-2, and IL-1 $\beta$ reveals intrinsic functional plasticity. Proc Natl Acad Sci 107: 1096110966.

Constantinides MG, McDonald BD, Verhoef PA, Bendelac A. 2014. A committed precursor to innate lymphoid cells Nature 508: 397-401.

Crellin NK, Trifari S, Kaplan CD, Satoh-Takayama N, Di Santo JP, Spits H. 2010. Regulation of cytokine secretion in human $\mathrm{CD} 127^{+}$LTi-like innate lymphoid cells by Tolllike receptor 2. Immunity 33: 752-764.

Cupedo T, Crellin NK, Papazian N, Rombouts EJ, Weijer K, Grogan JL, Fibbe WE, Cornelissen JJ, Spits H. 2009. Human fetal lymphoid tissue-inducer cells are interleukin 17-producing precursors to $\mathrm{RORC}^{+} \mathrm{CD} 127^{+}$natural killer-like cells. Nat Immunol 10: 66-74.

Dadi S, Chhangawala S, Whitlock BM, Franklin RA, Luo CT, Oh SA, Toure A, Pritykin Y, Huse M, Leslie CS, et al. 2016 Cancer immunosurveillance by tissue-resident innate lymphoid cells and innate-like T cells. Cell 164: 365-377.

Daussy C, Faure F, Mayol K, Viel S, Gasteiger G, Charrier E, Bienvenu J, Henry T, Debien E, Hasan UA, et al. 2014. Tbet and Eomes instruct the development of two distinct natural killer cell lineages in the liver and in the bone marrow. J Exp Med 211: 563-577.

Dent LA, Strath M, Mellor AL, Sanderson CJ. 1990. Eosinophilia in transgenic mice expressing interleukin 5. J Exp Med 172: 1425-1431.

Diefenbach A, Colonna M, Koyasu S. 2014. Development, differentiation, and diversity of innate lymphoid cells Immunity 41: 354-365.

Doherty TA, Khorram N, Lund S, Mehta AK, Croft M, Broide DH. 2013. Lung type 2 innate lymphoid cells express cysteinyl leukotriene receptor 1 , which regulates $\mathrm{T}_{\mathrm{H}} 2$ cytokine production. $J$ Allergy Clin Immunol 132: 205-213.

Duerr CU, McCarthy CD, Mindt BC, Rubio M, Meli AP, Pothlichet J, Eva MM, Gauchat JF, Qureshi ST, Mazer BD, et al. 2016. Type I interferon restricts type 2 immunopathology through the regulation of group 2 innate lymphoid cells. Nat Immunol 17: 65-75.

Ealey KN, Moro K, Koyasu S. 2017. Are ILC2s Jekyll and Hyde in airway inflammation? Immunol Rev 278: 207218.

Eberl G, Marmon S, Sunshine MJ, Rennert PD, Choi Y, Littman DR. 2004. An essential function for the nuclear receptor ROR $\gamma \mathrm{t}$ in the generation of fetal lymphoid tissue inducer cells. Nat Immunol 5: 64-73.

Eberl G, Colonna M, Di Santo JP, McKenzie AN. 2015. Innate lymphoid cells. Innate lymphoid cells: A new paradigm in immunology. Science 348: aaa6566.

Eisenring M, vom Berg J, Kristiansen G, Saller E, Becher B. 2010. IL-12 initiates tumor rejection via lymphoid tissueinducer cells bearing the natural cytotoxicity receptor NKp46. Nat Immunol 11: 1030-1038.

Eyerich S, Eyerich K, Cavani A, Schmidt-Weber C. 2010. IL17 and IL-22: Siblings, not twins. Trends Immunol 31: 354-361.
Fort MM, Cheung J, Yen D, Li J, Zurawski SM, Lo S, Menon S, Clifford T, Hunte B, Lesley R, et al. 2001. IL-25 induces IL-4, IL-5, and IL-13 and Th2-associated pathologies in vivo. Immunity 15: 985-995.

Fuchs A, Vermi W, Lee JG, Lonardi S, Gilfillan S, Newberry RD, Cella M, Colonna M. 2013. Intraepithelial type 1 innate lymphoid cells are a unique subset of IL-12- and IL-15-responsive IFN- $\gamma$-producing cells. Immunity 38: 769-781.

Gasteiger G, Fan X, Dikiy S, Lee SY, Rudensky AY. 2015. Tissue residency of innate lymphoid cells in lymphoid and non-lymphoid organs. Science 350: 981-985.

Grabstein KH, Eisenman J, Shanebeck K, Rauch C, Srinivasan S, Fung V, Beers C, Richardson J, Schoenborn MA, Ahdieh M, et al. 1994. Cloning of a T cell growth factor that interacts with the $\beta$ chain of the interleukin- 2 receptor. Science 264: 965-968.

Grunig G, Warnock M, Wakil AE, Venkayya R, Brombacher F, Rennick DM, Sheppard D, Mohrs M, Donaldson DD, Locksley RM, et al. 1998. Requirement for IL-13 independently of IL-4 in experimental asthma. Science 282: 22612263.

Hazenberg MD, Spits H. 2014. Human innate lymphoid cells. Blood 124: 700-709.

Hernandez PP, Mahlakoiv T, Yang I, Schwierzeck V, Nguyen N, Guendel F, Gronke K, Ryffel B, Holscher C, Dumoutier $L$, et al. 2015. Interferon- $\lambda$ and interleukin 22 act synergistically for the induction of interferon-stimulated genes and control of rotavirus infection. Nat Immunol 16: 698707.

Hogan SP, Rosenberg HF, Moqbel R, Phipps S, Foster PS, Lacy P, Kay AB, Rothenberg ME. 2008. Eosinophils: Biological properties and role in health and disease. Clin Exp Allergy 38: 709-750.

Hoorweg K, Peters CP, Cornelissen F, Aparicio-Domingo P, Papazian N, Kazemier G, Mjosberg JM, Spits H, Cupedo T. 2012. Functional differences between human NKp44and $\mathrm{NKp}_{4} 4^{+} \mathrm{RORC}^{+}$innate lymphoid cells. Front Immunol 3: 72 .

Hoyler T, Klose CS, Souabni A, Turqueti-Neves A, Pfeifer D, Rawlins EL, Voehringer D, Busslinger M, Diefenbach A. 2012. The transcription factor GATA-3 controls cell fate and maintenance of type 2 innate lymphoid cells. Immunity 37: 634-648.

Huang Y, Guo L, Qiu J, Chen X, Hu-Li J, Siebenlist U, Williamson PR, Urban JF Jr, Paul WE. 2015. IL-25-responsive, lineage-negative KLRG ${ }^{\text {hi }}$ cells are multipotential "inflammatory" type 2 innate lymphoid cells. Nat Immunol 16: 161-169.

Huber S, Gagliani N, Zenewicz LA, Huber FJ, Bosurgi L, Hu B, Hedl M, Zhang W, O'Connor W Jr, Murphy AJ, et al. 2012. IL-22BP is regulated by the inflammasome and modulates tumorigenesis in the intestine. Nature 491: 259-263.

Hughes T, Becknell B, Freud AG, McClory S, Briercheck E, Yu J, Mao C, Giovenzana C, Nuovo G, Wei L, et al. 2010. Interleukin-1 $\beta$ selectively expands and sustains interleukin- $22^{+}$immature human natural killer cells in secondary lymphoid tissue. Immunity 32: 803-814.

Huntington ND. 2014. The unconventional expression of IL-15 and its role in NK cell homeostasis. Immunol Cell Biol 92: 210-213. 
Innate Lymphoid Cells as Cytokine Hubs

Ikutani M, Yanagibashi T, Ogasawara M, Tsuneyama K, Yamamoto S, Hattori Y, Kouro T, Itakura A, Nagai Y, Takaki S, et al. 2012. Identification of innate IL-5-producing cells and their role in lung eosinophil regulation and antitumor immunity. J Immunol 188: 703-713.

Jabeen R, Kaplan MH. 2012. The symphony of the ninth: The development and function of Th9 cells. Curr Opin Immunol 24: 303-307.

Kang MJ, Lee CG, Lee JY, Dela Cruz CS, Chen ZJ, Enelow R, Elias JA. 2008. Cigarette smoke selectively enhances viral PAMP- and virus-induced pulmonary innate immune and remodeling responses in mice. J Clin Invest 118: 2771-2784.

Kearley J, Erjefalt JS, Andersson C, Benjamin E, Jones CP, Robichaud A, Pegorier S, Brewah Y, Burwell TJ, Bjermer L, et al. 2011. IL-9 governs allergen-induced mast cell numbers in the lung and chronic remodeling of the airways. Am J Respir Crit Care Med 183: 865-875.

Kennedy MK, Glaccum M, Brown SN, Butz EA, Viney JL, Embers M, Matsuki N, Charrier K, Sedger L, Willis CR, et al. 2000. Reversible defects in natural killer and memory CD8 T cell lineages in interleukin 15-deficient mice. J Exp Med 191: 771-780.

Kim BS, Siracusa MC, Saenz SA, Noti M, Monticelli LA, Sonnenberg GF, Hepworth MR, Van Voorhees AS, Comeau MR, Artis D. 2013. TSLP elicits IL-33-independent innate lymphoid cell responses to promote skin inflammation. Sci Transl Med 5: 170ra116.

Kim HY, Lee HJ, Chang YJ, Pichavant M, Shore SA, Fitzgerald KA, Iwakura Y, Israel E, Bolger K, Faul J, et al. 2014 Interleukin-17-producing innate lymphoid cells and the NLRP3 inflammasome facilitate obesity-associated airway hyperreactivity. Nat Med 20: 54-61.

Kirchberger S, Royston DJ, Boulard O, Thornton E, Franchini F, Szabady RL, Harrison O, Powrie F. 2013. Innate lymphoid cells sustain colon cancer through production of interleukin-22 in a mouse model. J Exp Med 210: 917931.

Klose CS, Kiss EA, Schwierzeck V, Ebert K, Hoyler T, d'Hargues Y, Goppert N, Croxford AL, Waisman A, Tanriver Y, et al. 2013. A T-bet gradient controls the fate and function of CCR6 ${ }^{-} \mathrm{ROR}^{+} \mathrm{t}^{+}$innate lymphoid cells. Nature 494: 261-265.

Klose CS, Flach M, Mohle L, Rogell L, Hoyler T, Ebert K, Fabiunke C, Pfeifer D, Sexl V, Fonseca-Pereira D, et al. 2014. Differentiation of type 1 ILCs from a common progenitor to all helper-like innate lymphoid cell lineages. Cell 157: 340-356.

Kopf M, Brombacher F, Hodgkin PD, Ramsay AJ, Milbourne EA, Dai WJ, Ovington KS, Behm CA, Kohler G, Young IG, et al. 1996. IL-5-deficient mice have a developmental defect in $\mathrm{CD}^{+} \mathrm{B}-1$ cells and lack eosinophilia but have normal antibody and cytotoxic $\mathrm{T}$ cell responses. Immunity 4: 15-24.

Liang HE, Reinhardt RL, Bando JK, Sullivan BM, Ho IC, Locksley RM. 2011. Divergent expression patterns of IL4 and IL-13 define unique functions in allergic immunity. Nat Immunol 13: 58-66.

Licona-Limon P, Henao-Mejia J, Temann AU, Gagliani N, Licona-Limon I, Ishigame H, Hao L, Herbert DR, Flavell RA. 2013. Th9 cells drive host immunity against gastrointestinal worm infection. Immunity 39: 744-757.
Lim AI, Menegatti S, Bustamante J, Le Bourhis L, Allez M, Rogge L, Casanova JL, Yssel H, Di Santo JP. 2016. IL-12 drives functional plasticity of human group 2 innate lymphoid cells. J Exp Med 213: 569-583.

Lim AI, Li Y, Lopez-Lastra S, Stadhouders R, Paul F, Casrouge A, Serafini N, Puel A, Bustamante J, Surace L, et al. 2017. Systemic human ILC precursors provide a substrate for tissue ILC differentiation. Cell 168: 10861100, e1010.

Longman RS, Diehl GE, Victorio DA, Huh JR, Galan C, Miraldi ER, Swaminath A, Bonneau R, Scherl EJ, Littman DR. 2014. $\mathrm{CX}_{3} \mathrm{CR}^{+}$mononuclear phagocytes support colitis-associated innate lymphoid cell production of IL22. J Exp Med 211: 1571-1583.

Lopez AF, Sanderson CJ, Gamble JR, Campbell HD, Young IG, Vadas MD. 1988. Recombinant human interleukin 5 is a selective activator of human eosinophil function. J Exp Med 167: 219-224.

Lopez-Castejon G, Brough D. 2011. Understanding the mechanism of IL-1 $\beta$ secretion. Cytokine Growth Factor Rev 22: 189-195.

Maloy KJ, Powrie F. 2011. Intestinal homeostasis and its breakdown in inflammatory bowel disease. Nature 474: 298-306.

Matsuki A, Takatori H, Makita S, Yokota M, Tamachi T, Suto A, Suzuki K, Hirose K, Nakajima H. 2017. T-bet inhibits innate lymphoid cell-mediated eosinophilic airway inflammation by suppressing IL-9 production. J Allergy Clin Immunol 139: 1355-1367.

Mebius RE, Rennert P, Weissman IL. 1997. Developing lymph nodes collect $\mathrm{CD} 4^{+} \mathrm{CD} 3^{-} \mathrm{LT}^{+}$cells that can differentiate to APC, NK cells, and follicular cells but not T or B cells. Immunity 7: 493-504.

Mishra A, Rothenberg ME. 2003. Intratracheal IL-13 induces eosinophilic esophagitis by an IL-5, eotaxin-1, and STAT6-dependent mechanism. Gastroenterology 125: 1419-1427.

Mjosberg JM, Trifari S, Crellin NK, Peters CP, van Drunen CM, Piet B, Fokkens WJ, Cupedo T, Spits H. 2011. Human IL-25- and IL-33-responsive type 2 innate lymphoid cells are defined by expression of CRTH2 and CD161. Nat Immunol 12: 1055-1062.

Mjosberg J, Bernink J, Golebski K, Karrich JJ, Peters CP, Blom B, te Velde AA, Fokkens WJ, van Drunen CM, Spits H. 2012. The transcription factor GATA3 is essential for the function of human type 2 innate lymphoid cells. Immunity 37: 649-659.

Mohapatra A, Van Dyken SJ, Schneider C, Nussbaum JC, Liang HE, Locksley RM. 2016. Group 2 innate lymphoid cells utilize the IRF4-IL-9 module to coordinate epithelial cell maintenance of lung homeostasis. Mucosal Immunol 9: 275-286.

Molofsky AB, Van Gool F, Liang HE, Van Dyken SJ, Nussbaum JC, Lee J, Bluestone JA, Locksley RM. 2015. Interleukin-33 and interferon- $\gamma$ counter-regulate group 2 innate lymphoid cell activation during immune perturbation. Immunity 43: 161-174.

Montaldo E, Teixeira-Alves LG, Glatzer T, Durek P, Stervbo U, Hamann W, Babic M, Paclik D, Stolzel K, Grone J, et al. 2014. Human ROR $\gamma \mathrm{t}^{+} \mathrm{CD} 34^{+}$cells are lineage-specified progenitors of group $3 \mathrm{ROR} \gamma \mathrm{t}^{+}$innate lymphoid cells. Immunity 41: 988-1000. 
M. Nagasawa et al.

Monticelli LA, Sonnenberg GF, Abt MC, Alenghat T, Ziegler CG, Doering TA, Angelosanto JM, Laidlaw BJ, Yang CY, Sathaliyawala T, et al. 2011. Innate lymphoid cells promote lung-tissue homeostasis after infection with influenza virus. Nat Immunol 12: 1045-1054.

Moretti S, Renga G, Oikonomou V, Galosi C, Pariano M, Iannitti RG, Borghi M, Puccetti M, De Zuani M, Pucillo CE, et al. 2017. A mast cell-ILC2-Th9 pathway promotes lung inflammation in cystic fibrosis. Nat Commun 8: 14017.

Moro K, Yamada T, Tanabe M, Takeuchi T, Ikawa T, Kawamoto H, Furusawa J, Ohtani M, Fujii H, Koyasu S. 2010. Innate production of $\mathrm{T}_{\mathrm{H}} 2$ cytokines by adipose tissueassociated c-Kit ${ }^{+} \mathrm{Sca}-1^{+}$lymphoid cells. Nature 463: 540-544.

Moro K, Kabata H, Tanabe M, Koga S, Takeno N, Mochizuki M, Fukunaga K, Asano K, Betsuyaku T, Koyasu S. 2016. Interferon and IL-27 antagonize the function of group 2 innate lymphoid cells and type 2 innate immune responses. Nat Immunol 17: 76-86.

Neill DR, Wong SH, Bellosi A, Flynn RJ, Daly M, Langford TK, Bucks C, Kane CM, Fallon PG, Pannell R, et al. 2010. Nuocytes represent a new innate effector leukocyte that mediates type-2 immunity. Nature 464: 1367-1370.

Ohne Y, Silver JS, Thompson-Snipes L, Collet MA, Blanck JP, Cantarel BL, Copenhaver AM, Humbles AA, Liu YJ. 2016. IL-1 is a critical regulator of group 2 innate lymphoid cell function and plasticity. Nat Immunol 17: 646655.

O'Shea JJ, Paul WE. 2010. Mechanisms underlying lineage commitment and plasticity of helper $\mathrm{CD} 4^{+} \mathrm{T}$ cells. Science 327: 1098-1102.

Ouyang W, Valdez P. 2008. IL-22 in mucosal immunity. Mucosal Immunol 1: 335-338.

Park O, Wang H, Weng H, Feigenbaum L, Li H, Yin S, Ki SH, Yoo SH, Dooley S, Wang FS, et al. 2011. In vivo consequences of liver-specific interleukin-22 expression in mice: Implications for human liver disease progression. Hepatology 54: 252-261.

Pope SM, Brandt EB, Mishra A, Hogan SP, Zimmermann N, Matthaei KI, Foster PS, Rothenberg ME. 2001. IL-13 induces eosinophil recruitment into the lung by an IL-5and eotaxin-dependent mechanism. J Allergy Clin Immunol 108: 594-601.

Possot C, Schmutz S, Chea S, Boucontet L, Louise A, Cumano A, Golub R. 2011. Notch signaling is necessary for adult, but not fetal, development of ROR $\mathrm{t}^{+}$innate lymphoid cells. Nat Immunol 12: 949-958.

Price AE, Liang HE, Sullivan BM, Reinhardt RL, Eisley CJ, Erle DJ, Locksley RM. 2010. Systemically dispersed innate IL-13-expressing cells in type 2 immunity. Proc Natl Acad Sci 107: 11489-11494.

Reche PA, Soumelis V, Gorman DM, Clifford T, Liu M, Travis M, Zurawski SM, Johnston J, Liu YJ, Spits H, et al. 2001. Human thymic stromal lymphopoietin preferentially stimulates myeloid cells. J Immunol 167: 336343.

Robinette ML, Fuchs A, Cortez VS, Lee JS, Wang Y, Durum SK, Gilfillan S, Colonna M, et al. 2015. Transcriptional programs define molecular characteristics of innate lymphoid cell classes and subsets. Nat Immunol 16: 306-317.
Robinette ML, Bando JK, Song W, Ulland TK, Gilfillan S, Colonna M. 2017. IL-15 sustains IL-7R-independent ILC2 and ILC3 development. Nat Commun 8: 14601.

Rochman Y, Spolski R, Leonard WJ. 2009. New insights into the regulation of T cells by $\gamma_{c}$ family cytokines. Nat Rev Immunol 9: 480-490.

Roediger B, Kyle R, Tay SS, Mitchell AJ, Bolton HA, Guy TV, Tan SY, Forbes-Blom E, Tong PL, Koller Y, et al. 2015. IL2 is a critical regulator of group 2 innate lymphoid cell function during pulmonary inflammation. J Allergy Clin Immunol 136: 1653-1663, e1651-e1657.

Sabat R, Ouyang W, Wolk K. 2014. Therapeutic opportunities of the IL-22-IL-22R1 system. Nat Rev Drug Discov 13: 21-38.

Salimi M, Barlow JL, Saunders SP, Xue L, Gutowska-Owsiak D, Wang X, Huang LC, Johnson D, Scanlon ST, McKenzie AN, et al. 2013. A role for IL-25 and IL-33-driven type-2 innate lymphoid cells in atopic dermatitis. J Exp Med 210: 2939-2950.

Satoh-Takayama N, Dumoutier L, Lesjean-Pottier S, Ribeiro VS, Mandelboim O, Renauld JC, Vosshenrich CA, Di Santo JP. 2009. The natural cytotoxicity receptor NKp46 is dispensable for IL-22-mediated innate intestinal immune defense against Citrobacter rodentium. J Immunol 183: 6579-6587.

Sawa S, Cherrier M, Lochner M, Satoh-Takayama N, Fehling HJ, Langa F, Di Santo JP, Eberl G. 2010. Lineage relationship analysis of ROR $\mathrm{t}^{+}$innate lymphoid cells. Science 330: 665-669.

Schmitz J, Owyang A, Oldham E, Song Y, Murphy E, McClanahan TK, Zurawski G, Moshrefi M, Qin J, Li X, et al. 2005. IL-33, an interleukin-1-like cytokine that signals via the IL-1 receptor-related protein ST2 and induces Thelper type 2-associated cytokines. Immunity 23: 479-490.

Schoenborn JR, Wilson CB. 2007. Regulation of interferon- $\gamma$ during innate and adaptive immune responses. Adv Immunol 96: 41-101.

Scoville SD, Mundy-Bosse BL, Zhang MH, Chen L, Zhang X, Keller KA, Hughes T, Chen L, Cheng S, Bergin SM, et al. 2016. A progenitor cell expressing transcription factor ROR $\gamma$ t generates all human innate lymphoid cell subsets. Immunity 44: 1140-1150.

Shikhagaie MM, Bjorklund AK, Mjosberg J, Erjefalt JS, Cornelissen AS, Ros XR, Bal SM, Koning JJ, Mebius RE, Mori M, et al. 2017. Neuropilin-1 is expressed on lymphoid tissue residing LTi-like group 3 innate lymphoid cells and associated with ectopic lymphoid aggregates. Cell Rep 18: 1761-1773.

Silver JS, Kearley J, Copenhaver AM, Sanden C, Mori M, Yu L, Pritchard GH, Berlin AA, Hunter CA, Bowler R, et al. 2016. Inflammatory triggers associated with exacerbations of COPD orchestrate plasticity of group 2 innate lymphoid cells in the lungs. Nat Immunol 17: 626-635.

Spits H, Artis D, Colonna M, Diefenbach A, Di Santo JP, Eberl G, Koyasu S, Locksley RM, McKenzie AN, Mebius $\mathrm{RE}$, et al. 2013. Innate lymphoid cells-A proposal for uniform nomenclature. Nat Rev Immunol 13: 145-149.

Spits H, Bernink JH, Lanier L. 2016. NK cells and type 1 innate lymphoid cells: Partners in host defense. Nat Immunol 17: 758-764.

Takatori H, Kanno Y, Watford WT, Tato CM, Weiss G, Ivanov II, Littman DR, O’Shea JJ. 2009. Lymphoid tissue 
Innate Lymphoid Cells as Cytokine Hubs

inducer-like cells are an innate source of IL-17 and IL-22. J Exp Med 206: 35-41.

Teng MW, Bowman EP, McElwee JJ, Smyth MJ, Casanova JL, Cooper AM, Cua DJ. 2015. IL-12 and IL-23 cytokines: From discovery to targeted therapies for immune-mediated inflammatory diseases. Nat Med 21: 719-729.

Turner JE, Morrison PJ, Wilhelm C, Wilson M, Ahlfors H, Renauld JC, Panzer U, Helmby H, Stockinger B. 2013. IL9-mediated survival of type 2 innate lymphoid cells promotes damage control in helminth-induced lung inflammation. J Exp Med 210: 2951-2965.

Valizadeh A, Khosravi A, Zadeh LJ, Parizad EG. 2015. Role of IL-25 in Immunity. J Clin Diagn Res 9: OE01-OE04.

van de Pavert SA, Ferreira M, Domingues RG, Ribeiro H, Molenaar R, Moreira-Santos L, Almeida FF, Ibiza S, Barbosa I, Goverse G, et al. 2014. Maternal retinoids control type 3 innate lymphoid cells and set the offspring immunity. Nature 508: 123-127.

Vely F, Barlogis V, Vallentin B, Neven B, Piperoglou C, Ebbo M, Perchet T, Petit M, Yessaad N, Touzot F, et al. 2016. Evidence of innate lymphoid cell redundancy in humans. Nat Immunol 17: 1291-1299.

Vonarbourg C, Mortha A, Bui VL, Hernandez PP, Kiss EA, Hoyler T, Flach M, Bengsch B, Thimme R, Holscher C, et al. 2010. Regulated expression of nuclear receptor ROR $\gamma \mathrm{t}$ confers distinct functional fates to NK cell receptor-expressing ROR $\gamma \mathrm{t}^{+}$innate lymphocytes. Immunity 33: 736751.

von Moltke J, Ji M, Liang HE, Locksley RM. 2016. Tuft-cellderived IL-25 regulates an intestinal ILC2-epithelial response circuit. Nature 529: 221-225.

West EE, Kashyap M, Leonard WJ. 2012. TSLP: A Key regulator of asthma pathogenesis. Drug Discov Today Dis Mech doi: 10.1016/j.ddmec.2012.09.003.

West NR, McCuaig S, Franchini F, Powrie F. 2015. Emerging cytokine networks in colorectal cancer. Nat Rev Immunol 15: 615-629.

Wilhelm C, Hirota K, Stieglitz B, Van Snick J, Tolaini M, Lahl K, Sparwasser T, Helmby H, Stockinger B. 2011. An IL-9 fate reporter demonstrates the induction of an innate IL-9 response in lung inflammation. Nat Immunol 12: 1071-1077.

Wolk K, Witte E, Witte K, Warszawska K, Sabat R. 2010. Biology of interleukin-22. Semin Immunopathol 32: 1731.

Wynn TA. 2003. IL-13 effector functions. Annu Rev Immunol 21: 425-456.

Xu W, Domingues RG, Fonseca-Pereira D, Ferreira M, Ribeiro H, Lopez-Lastra S, Motomura Y, Moreira-Santos L,
Bihl F, Braud V, et al. 2015. NFIL3 orchestrates the emergence of common helper innate lymphoid cell precursors. Cell Rep 10: 2043-2054.

Xue L, Salimi M, Panse I, Mjosberg JM, McKenzie AN, Spits H, Klenerman P, Ogg G. 2014. Prostaglandin D2 activates group 2 innate lymphoid cells through chemoattractant receptor-homologous molecule expressed on $\mathrm{T}_{\mathrm{H}} 2$ cells. $J$ Allergy Clin Immunol 133: 1184-1194.

Yamaguchi Y, Hayashi Y, Sugama Y, Miura Y, Kasahara T, Kitamura S, Torisu M, Mita S, Tominaga A, Takatsu K. 1988. Highly purified murine interleukin 5 (IL-5) stimulates eosinophil function and prolongs in vitro survival. IL-5 as an eosinophil chemotactic factor. J Exp Med 167: 1737-1742.

Yang Q, Li F, Harly C, Xing S, Ye L, Xia X, Wang H, Wang X, Yu S, Zhou X, et al. 2015. TCF-1 upregulation identifies early innate lymphoid progenitors in the bone marrow. Nat Immunol 16: 1044-1050.

Yao W, Zhang Y, Jabeen R, Nguyen ET, Wilkes DS, Tepper RS, Kaplan MH, Zhou B. 2013. Interleukin-9 is required for allergic airway inflammation mediated by the cytokine TSLP. Immunity 38: 360-372.

Yokota YM, Mori A, Sugawara S, Adachi S, Nishikawa S, Gruss P. 1999. Development of peripheral lymphoid organs and natural killer cells depends on the helix-loophelix inhibitor Id2. Nature 397: 702-706.

Yu X, Wang Y, Deng M, Li Y, Ruhn KA, Zhang CC, Hooper LV. 2014. The basic leucine zipper transcription factor NFIL3 directs the development of a common innate lymphoid cell precursor. eLife 3: e04406.

Zaph C, Du Y, Saenz SA, Nair MG, Perrigoue JG, Taylor BC, Troy AE, Kobuley DE, Kastelein RA, Cua DJ, et al. 2008. Commensal-dependent expression of IL-25 regulates the IL-23-IL-17 axis in the intestine. J Exp Med 205: 21912198.

Zheng Y, Valdez PA, Danilenko DM, Hu Y, Sa SM, Gong Q, Abbas AR, Modrusan Z, Ghilardi N, de Sauvage FJ, et al. 2008. Interleukin- 22 mediates early host defense against attaching and effacing bacterial pathogens. Nat Med 14: 282-289.

Zhu Z, Homer RJ, Wang Z, Chen Q, Geba GP, Wang J, Zhang Y, Elias JA. 1999. Pulmonary expression of interleukin-13 causes inflammation, mucus hypersecretion, subepithelial fibrosis, physiologic abnormalities, and eotaxin production. J Clin Invest 103: 779-788.

Ziegler SF. 2012. Thymic stromal lymphopoietin and allergic disease. J Allergy Clin Immunol 130: 845-852. 


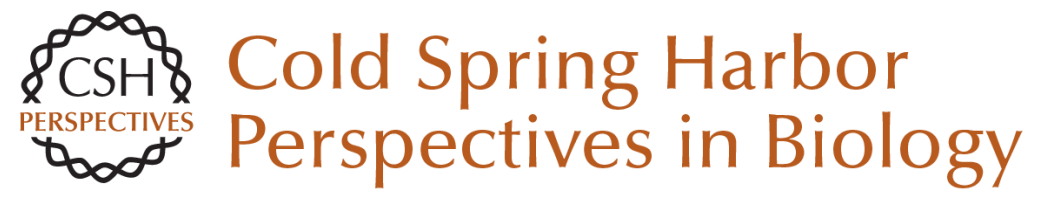

\title{
Innate Lymphoid Cells (ILCs): Cytokine Hubs Regulating Immunity and Tissue Homeostasis
}

\author{
Maho Nagasawa, Hergen Spits and Xavier Romero Ros
}

Cold Spring Harb Perspect Biol 2018; doi: 10.1101/cshperspect.a030304 originally published online December 11, 2017

\section{Subject Collection Cytokines}

Interleukin (IL)-33 and the IL-1 Family of Cytokines

--Regulators of Inflammation and Tissue

Homeostasis

Ajithkumar Vasanthakumar and Axel Kallies

Targeting IL-10 Family Cytokines for the Treatment of Human Diseases

Xiaoting Wang, Kit Wong, Wenjun Ouyang, et al.

\section{Cytokine-Mediated Regulation of CD8 T-Cell} Responses During Acute and Chronic Viral Infection

Masao Hashimoto, Se Jin Im, Koichi Araki, et al.

Cytokines in Cancer Immunotherapy

Thomas A. Waldmann

The Tumor Necrosis Factor Family: Family Conventions and Private Idiosyncrasies David Wallach

The Interferon (IFN) Class of Cytokines and the IFN Regulatory Factor (IRF) Transcription Factor Family

Hideo Negishi, Tadatsugu Taniguchi and Hideyuki Yanai
Interferon $\gamma$ and Its Important Roles in Promoting and Inhibiting Spontaneous and Therapeutic Cancer Immunity

Elise Alspach, Danielle M. Lussier and Robert D. Schreiber

Inflammasome-Dependent Cytokines at the Crossroads of Health and Autoinflammatory Disease

Hanne Van Gorp, Nina Van Opdenbosch and Mohamed Lamkanfi

Innate Lymphoid Cells (ILCs): Cytokine Hubs

Regulating Immunity and Tissue Homeostasis Maho Nagasawa, Hergen Spits and Xavier Romero Ros

T Helper Cell Differentiation, Heterogeneity, and

Plasticity Jinfang Zhu

Development, Diversity, and Function of Dendritic

Cells in Mouse and Human

David A. Anderson III, Kenneth M. Murphy and Carlos G. Briseño

Cytokines and Long Noncoding RNAs Susan Carpenter and Katherine A. Fitzgerald

For additional articles in this collection, see http://cshperspectives.cshlp.org/cgi/collection/

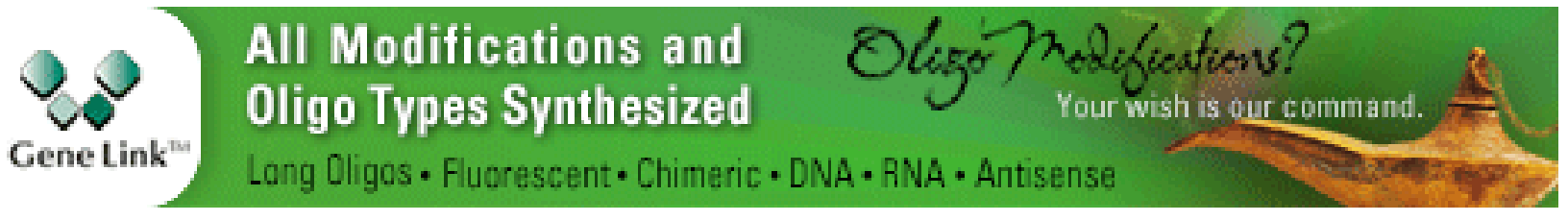


Role of the $\beta$ Common $(\beta \mathrm{c})$ Family of Cytokines in Health and Disease

Timothy R. Hercus, Winnie L. T. Kan, Sophie E. Broughton, et al.

Interleukin (IL)-12 and IL-23 and Their Conflicting Roles in Cancer Juming Yan, Mark J. Smyth and Michele W.L. Teng
Negative Regulation of Cytokine Signaling in Immunity

Akihiko Yoshimura, Minako Ito, Shunsuke Chikuma, et al.

Cancer Inflammation and Cytokines

Maria Rosaria Galdiero, Gianni Marone and Alberto Mantovani

For additional articles in this collection, see http://cshperspectives.cshlp.org/cgi/collection/

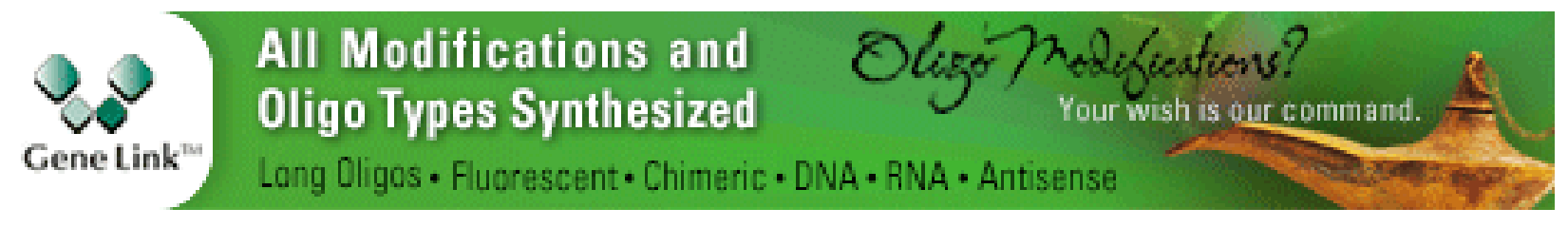

Copyright @ 2018 Cold Spring Harbor Laboratory Press; all rights reserved 